\title{
Role of Vitamin $D$ in the Development of Obesity
}

\author{
Rol de la Vitamina $D$ en el Desarrollo de la Obesidad \\ Merino, O. ${ }^{1,2}$; Gregório, B. ${ }^{3}$; Sampaio, F. ${ }^{3}$; Sánchez, R. ${ }^{1,4}$ \& Risopatrón, J. ${ }^{1,5}$
}

MERINO, O.; GREGÓRIO, B.; SAMPAIO, F.; SÁNCHEZ, R. \& RISOPATRÓN, J. Role of vitamin D in the development of obesity. Int. J. Morphol., 35(4):1568-1575, 2017.

SUMMARY: Antecedents in the literature suggest that vitamin D (VD) play a role in overweigh/obesity. The present study evaluated the effect of VD deficiency diet intake and fat hight on overweight/obesity about white adipose tissue (WAT) and body mass (BM) gain. Animals were divided into four experimental groups according to the lipid and VD content of their diets; G1: CVD+ (C: control diet with VD+; n=5), G2: CVD- (control diet without VD-; n=5), G3: HFVD+ (high fat diet, with VD+; n=5), G4: HFVD- (HF diet without VD-; $n=5$ ). The diets were administered for three months and BW was monitored weekly. At the end of this period all animals were euthanized. Epididymal (EFM), retroperitoneal (RFM) and subcutaneous (SFM) fat mass were removed, weighted. At 12 weeks the body mass of the animals that were fed without VD- diets; G2: $507.60 \pm 17.31 \mathrm{~g}$, and G4: $528.50 \pm 13.50 \mathrm{~g}$ were significantly higher $(\mathrm{p}<0.05)$, than the counterparts G1: $485.0 \pm 11.29 \mathrm{~g}$ and G3: 521.20 $\pm 26.20 \mathrm{~g}$ respectively. Similarly, the animals fed with VDdiets had a greater EFM and SFM $(\mathrm{p}<0.05)$ compared with the respective controls $(\mathrm{VD}+)$. Nevertheless, the animals fed with high fat diet had equal RFM (G3: 12.2 $\pm 4.10 \mathrm{~g}, \mathrm{G} 4: 12.88 \pm 2.3 \mathrm{~g}, \mathrm{p}>0.05)$. The results demonstrate that the nutrition of rats with diet deficient in VD and high fat, promotes overweight by increasing fat deposits, suggestion a cause-effect relationship between VD deficiency and overweight. These results suggest that VD deficiency increases the risk of visceral fat obesity in males.

KEY WORDS: VD deficiency; Gain weight; Fat gain; Fat pad; Visceral fat obesity.

\section{INTRODUCTION}

Obesity is a global epidemic (Popkin, 2010) his prevalence one of the major public health concerns (Kayaniyil et al., 2011). The obesity relates with among an energy-dense, high-fat diet, its availability and promotion, sedentary lifestyles, which conducive to the development of obesity (James et al., 2001). Obesity is characterized by a significant increase of adiposity (Nishimura et al., 2007). The adipose tissue is considered to be endocrine organ (Lehr et al., 2012), and a depot for the storage and release VD (Malmberg et al., 2014).

The relationship between overweight/obesity and VD deficiency has been suggested by several lines of evidence, both direct and indirect (vinh quoc Luong \& Nguyn, 2013). The VD deficiency is the most common nutritional deficiency in the world (Holick \& Chen, 2008). One of the major physiologic functions of VD is to maintain serum calcium and phosphorus levels in a healthy range to maintain a wide variety of metabolic functions, transcription regulation, and metabolism (Hossein-nezhad \& Holick, 2012). VD deficiency is associated with a greater risk of pathological conditions (Borges et al., 2016). In addition, the VD hormone has numerous non-calcemic activities (Bouillon et al., 2008), including regulation of adipocyte biology (Kong \& Li, 2006). Addition, the role for VD receptor (VDR) is linked to the regulation of global energy metabolism by regulating adipose tissue fat depot location and expansion (Wong, et al., 2009). However, the explanations and direction of causality the relationship between overweight/obesity and VD deficiency are unclear. The obesity is frequently cited as a cause of VD deficiency (Holick \& Chen, 2008). An important question is whether VD deficiency causes obesity (Pourshahidi, 2015).

\footnotetext{
${ }^{1}$ Center of Biotechnology in Reproduction (CEBIOR-BIOREN), Universidad de La Frontera, Temuco, Chile.

${ }^{2}$ Doctoral Program in Morphological Sciences, Faculty of Medicine, Universidad de La Frontera, Temuco, Chile.

${ }^{3}$ Department of Anatomy, State University of Rio de Janeiro, UERJ, Urogenital Research Unit, Biomedical Center, Rio de Janeiro, Brazil.

${ }^{4}$ Department Preclinical Sciences, Faculty of Medicine, Universidad de La Frontera, Temuco, Chile.

${ }^{5}$ Department of Basic Sciences, Faculty of Medicine, Universidad de La Frontera, Temuco, Chile.
} 
The increase of adipose tissue and body mass in overweight/obese subjects can be linked to a deficit of VD in the diet. Some studies suggest an inverse relation between body mass index (BMI) and fat mass, with low concentrations of 25-hydroxyvitamin D $(25(\mathrm{OH}) \mathrm{D})$ (Vimaleswaran et al., 2013). Others studies have demonstrated that VD deficiency this linked with visceral fat obesity (VFO) (Zhang et al., 2015). There is evidence that VD metabolism, storage, and action both influence and are influenced by adiposity. Fat accumulation in different areas represents different risk for metabolic disorders and visceral adipose tissue may be unique (Fox et al., 2007). Further, the visceral fat accumulation (waist circumference/ WC) (World Health Organization, 2000) is recognized as a risk factor for VD deficiency (Zhang et al.,).

The present study report on the VD deficiency dietary of rats (Sprague Dawley). It evaluated the effect of VD, deficiency at different diet, to increment adipose tissue, especially to epididymal (EFM), subcutaneous (SFM), retroperitoneal (RFM) and body mass. Few publications exist to date with information on the effects of VD deficiency adipose tissue Sprague Dawley rats.

\section{MATERIAL AND METHOD}

Experimental protocol: The study was approved by the Scientific Ethics Committee (SEC) of the La Frontera University (Protocol No 167/15; Act $\mathrm{N}^{\circ}$ 014/2016). The animals were maintained a temperature of $21 \pm 2{ }^{\circ} \mathrm{C}$ and controlled light cycle (12-12 h light/dark), with free access to water and food. All potential sources of ultraviolet light were eliminated to exclude the possibility of endogenous VD production in the skin.

Experimental design: Male Sprague-Dawley rats, sexually mature, 16 weeks old, were obtained from the Center for Excellence in Morphological and Surgical Studies (CEMyQ), Universidad de La Frontera, Temuco, Chile. All animals were housed in polycarbonate cages (five rats/cage). The rats were randomized into four study groups ( $\mathrm{n}=$ five/group) according to the lipid and VD content of their diets; G1: C/VD+ (C: control diet/ with VD+; $\mathrm{n}=5$ ), G2: C/VD- (control diet/ without VD-; $=5$ ), G3: HF/VD+ (high fat diet/ with VD+; n=5), Group 4: HF/VD- (high fat diet/ without VD-; n=5). The G1, G2 diets (14\% protein, $76 \%$ carbohydrates and $10 \%$ fat; $15.9 \mathrm{~kJ} /$ g) and G3 and G4, high-fat diets (HF) (14\% protein, 36\% carbohydrates and $50 \%$ fat; $20.9 \mathrm{~kJ} / \mathrm{g}$ ), both with and without VD, were prepared following the recommendations of the AIN93M (Reeves et al., 1993).
Table I. Composition of experimental diets. American Institute of Nutrition (AIN).

\begin{tabular}{lrrrr}
\hline $\begin{array}{l}\text { Nutrients } \\
(\mathrm{g} / \mathrm{Kg})\end{array}$ & $\begin{array}{r}\mathrm{C} / \mathrm{VD}+ \\
(\mathrm{G} 1)\end{array}$ & $\begin{array}{r}\mathrm{C} / \mathrm{VD}- \\
(\mathrm{G} 2)\end{array}$ & $\begin{array}{r}\mathrm{HF} / \mathrm{VD}+ \\
(\mathrm{G} 3)\end{array}$ & $\begin{array}{r}\text { HF/VD- } \\
(\mathrm{G} 4)\end{array}$ \\
\hline Corn starch & 620.7 & 620.7 & 347.7 & 347.7 \\
Casein & 140 & 140 & 175 & 175 \\
Sucrose & 100 & 100 & 100 & 100 \\
Soybean oil & 40 & 40 & 40 & 40 \\
Lard & 0 & 0 & 238 & 238 \\
Fiber & 50 & 50 & 50 & 50 \\
Mineral mix AIN 93 M & 35 & 35 & 35 & 35 \\
Vitamin mix & 10 & 10 & 10 & 10 \\
Vitamin D3 (IU/Kg diet) & 1000 & 0.0 & 1000 & 0.0 \\
L-cysteine & 1.8 & 1.8 & 1.8 & 1.8 \\
Choline Bitartrate & 2.5 & 2.5 & 2.5 & 2.5 \\
Antioxidant - BHT & 0.08 & 0.08 & 0.06 & 0.06 \\
Total mass (g) & 1000 & 1000 & 1000 & 1000 \\
Energy (Kcal/Kg) & 3810 & 3810 & 5000 & 5000 \\
Carbohydrate (\%) & 75.6 & 75.6 & 35.8 & 35.8 \\
Protein (\%) & 14.8 & 14.8 & 14.1 & 14.1 \\
Fat (\%) & 9.4 & 9.4 & 50 & 50 \\
\hline
\end{tabular}

The males were divided into four experimental groups according to the lipid and VD content of their diets: G1: diet control C, n=5, G2: diet C, deficient VD, n=5, G3: high fat diet in saturated fatty acids, based on lard, $\mathrm{n}=5, \mathrm{G} 4$ : HF diet, deficient VD, $\mathrm{n}=5$. The $\mathrm{G} 1$ and G2 diets, $14.8 \%$ protein, $75.6 \%$ carbohydrates and $9.4 \%$ lipids with a total energy of $15.9 \mathrm{~kJ} / \mathrm{g}$ and G3 and G4 diets (high-fat diets) $14.1 \%$ protein, $35.8 \%$ carbohydrates and $50 \%$ fat with a total energy of $20.9 \mathrm{~kJ} / \mathrm{g}$. The diets were made by Pragsolutions ${ }^{\circledR}$ (www.pragsolucoes.com.br).
The diets were made by Pragsolutions ${ }^{\circledR}$ (www.pragsolucoes.com.br) (Table I). The diets were administered to the rats from four to seven months of age. All of the study groups received water and food ad libitum, and their food intake was assessed daily. BM was monitored weekly until the end of the experiment. Food intake was measured daily. Energy intake was estimated as the product of food intake (g/day) by the energy content of the diet (kJ/day). At the end of this period all animals were euthanized by overdose anesthetic (4X) with an intraperitoneal injection of Ketamine-Xylazine. The subcutaneous (SFM), epidydimal (EFM) and retroperitoneal fat mass (RFM), were dissected bilaterally and weighed individually. An adiposity index was computed for each rodent as $100 \mathrm{x}$ (sum of fat pad weights)/(body weight) (Taylor \& Phillips, 1996).

Data analysis: Data were expressed as the mean \pm standard deviation (SD). Differences among the groups were tested with one-way ANOVA followed by Holm-Sidak post-hoc test. The effects of both the HF diet and the VD-, as 
independent factors, and the possible interactions between the factors were tested by two-way ANOVA. The $\mathrm{p}<0.05$ was considered statistically significant (Prism version 6.0 for Windows; GraphPad Software, San Diego, California, USA).

\section{RESULTS}

The groups started the experiment without any difference in baseline BM. To observe the effects of VD on BM, rats were fed diets G1, G2, G3 and G4 for 3 months.

Throughout the course of the study, the mean food intake of G3, G4 diets rats was significantly lower than the mean food intake of G1, G2 diets rats. In contrast, energy intake between the groups was elevated at 12 weeks (G3, G4 > G1, G2) (Table II). Adiposity index increased significantly in manner in obese animals (G3, G4 > G1, G2). Between the obese groups, G4 increased significantly $(\mathrm{p}<0.05)$ (Table II).

At 12 weeks of experiment, the animals belonging to $\mathrm{G} 2$ and $\mathrm{G} 4$ had higher BM (G2: $507.60 \pm 17.31 \mathrm{~g}$, and G4: $528.50 \pm 13.50 \mathrm{~g}$; respectively, $\mathrm{p}<0.05)$, than $\mathrm{G} 1$ and

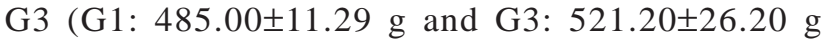
respectively) (Fig. 1). The mean BM of rats in the $\mathrm{G} 2$ indicated a significant gradual gain during 12 weeks of administration diet in comparison of G1 ( $\mathrm{p}<0.05)$. There was marked difference in BM of G1 and G2 throughout the 12 weeks of the study (Fig. 1) and there were significatives difference between the G3 and G4 ( $<<0.05)$.

\section{Visceral fat mass}

Epididymal fat pad: The animals belonging to $\mathrm{G} 2$ and G4 that consumed VD- deficient diets had higher EFM (G2: $9.72 \pm 1.59 \mathrm{~g}$, and $\mathrm{G} 4: 15.20 \pm 2.22 \mathrm{~g}$ respectively), than G1 and G3 that consumed VD+ in their diets (G1: $7.84 \pm 1.40 \mathrm{~g}$; G3: $13.20 \pm 4.44$ g respectively) ( $\mathrm{p}<0.05$ ) (Fig. 2).

Retroperitoneal fat pad: Animals the G1 and G2 had a

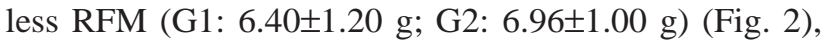
compared with the animals from G3 and G4 (G4:

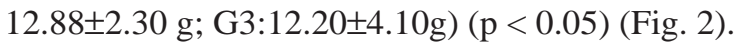

\section{Subcutaneous fat mass}

Subcutaneous fat pad (abdominal region): $\mathrm{G} 1$ and $\mathrm{G} 2$ had lower subcutaneous fat mass (SFM) (G1: 9.16 \pm 1.60 g, G2: $9.72 \pm 1.00 \mathrm{~g}$, respectively, compared with the G3 and G4 diets (G3: 12.06 $\pm 1.4 \mathrm{~g}, \mathrm{G} 4: 15.35 \pm 1.6 \mathrm{~g}$ respectively) ( $\mathrm{p}<0.05$ ) (Fig. 2).

VD deficient diets significantly affected BM and the fat mass of the groups $(p<0.05)$. VD deficiency was a significant factor in these parameters.

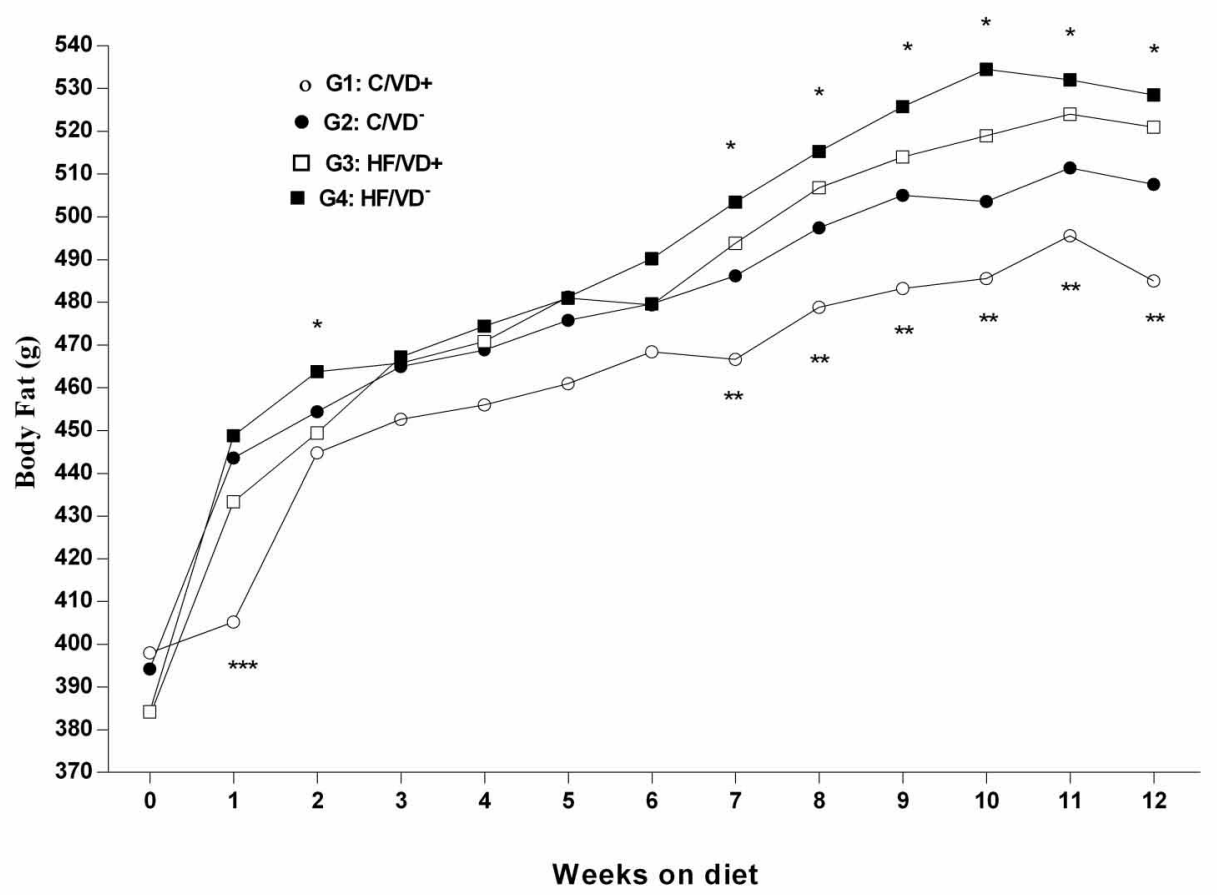

Fig. 1. Body mass (BM) is expressed as the mean $\pm \mathrm{SD}, \mathrm{n}$ $=5$, and was analyzed by oneway ANOVA and posthoc Holm-Sidak tests. $\mathrm{p}<0.05$ when: * compared with G1 in the same group and, ** compared with the VD counterpart. Groups: G1: C/ $\mathrm{VD}+$, control diet with VD, G2: C/VD- diet without VD, G3:HF/VD+, high-fat diet with VD, G4: HF/VD-, higt-fat diet without VD. 


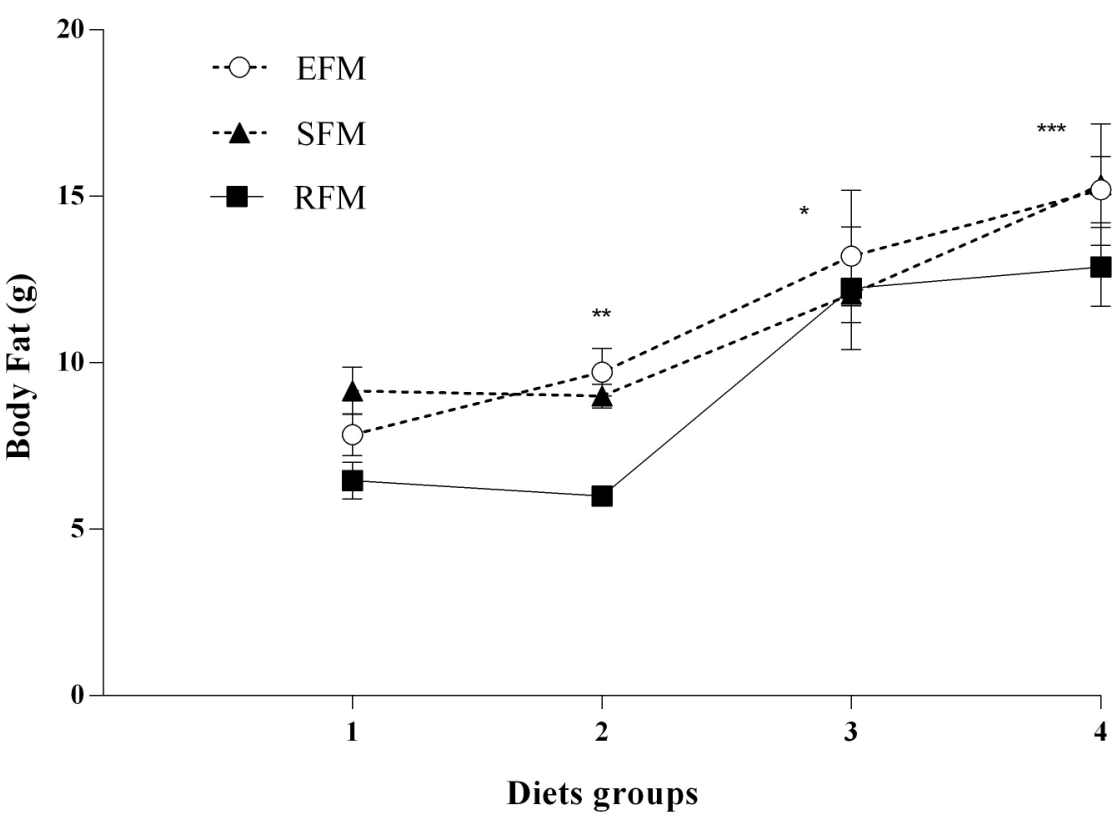

Fig. 2. Vitamin D and fat mass pads. Fat mass for all different fat pads measured [epididymal (EFM), subcutaneous (SFM) and retroperitoneal (RFM)]. * asterisks indicate significant differences among fat pads, $\mathrm{p}<$ 0.05. Fat mass pads is expressed as the mean $\pm \mathrm{SD}, \mathrm{n}=5$, and was analyzed by one-way ANOVA and posthoc HolmSidak tests. $\mathrm{p}<0.05$.

Diets groups

Table II. Daily mean food and calories consumption, and adiposity index among the groups.

\begin{tabular}{lrrrr}
\hline \multicolumn{1}{c}{ Data } & G1 & G2 & G3 & G4 \\
\hline Food intake (g/day) & $22.62 \pm 0.28 \mathrm{a}$ & $22.07 \pm 0.64 \mathrm{a}$ & $20.63 \pm 1.21 \mathrm{~b}$ & $20.99 \pm 1.00 \mathrm{~b}$ \\
Energy intake (kcal/day) & $305.83 \pm 44.62 \mathrm{a}$ & $295.31 \pm 33.15 \mathrm{a}$ & $371.41 \pm 65.12 \mathrm{c}$ & $379.04 \pm 50.01 \mathrm{c}$ \\
Adiposity index (\%) & $4.84^{\mathrm{a}}$ & $4.88^{\mathrm{a}}$ & $7.20 \mathrm{c}$ & $8.23 \mathrm{e}$ \\
\hline
\end{tabular}

Data expressed as means \pm SD. The lower case letters refer to the comparison between the groups. Two-Way ANOVA, post hoc Holm-Sidak's multiple comparisons test). a,b,c,d, e differents letters indicate significant differences, $\mathrm{P}<0.05$. Groups: G1: control diet, with VD; G2: control diet, without VD; G3: high-fat diet, with VD; G4: high-fat diet, without VD.

\section{DISCUSSION}

In this study, we investigated the impact of daily dietary intake of vitamin D deficient and diet-induced obesity on the changes of fat mass and body mass. Our data clearly show that diet intake deficiency of VD negatively impacts on adipose tissue stores. This conclusion is based on the phenotype of increased body and adipose tissue weights in male rats. The high-fat diets used in the present study was effective in promoting obesity, as demonstrated by an increased adiposity index (Table II) in association with a higher BM. This condition (obesity) was exacerbated by ingestion of a high-fat diet and VD deficient. Our study shown a significative negative association between deficiency VD intake and body fat mass (Fig. 2). Which is in accordance with Chang \& Kim (2017), demonstrated that dietary VD deficient exacerbates high fat diet-increased body weight gain and fat deposition, which is consistent with previous studies showing the effects of deficiency VD on diet-induced overweight/obesity (vinh quoc Luong \& Nguyn, 2013; Zhang et al., 2015; Chang \& Kim, 2017). The diets VD deficient significantly affected BM and the FM gain of the groups $(\mathrm{p}<0.05)$. The exacerbation obesity induced by high-fat diets and VD deficient, was confirmed by the increase in epididymal fat deposit (Fig 2). The VD could be involved in the pathogenesis of obesity this hypothesis is supported by experimental data showing regulatory effects of VD on adipose tissue and lipid storage (Koszowska et al., 2014). Narvaez et al. (2009) indicated that 1,25(OH)2D3 and the VDR likely function in a complex network that coordinately regulates adipose stores, and energy metabolism in response to physiological and nutritional cues, with high affinity and specificity (Demay, 2006) in our study probably dietary VD deficiency generates 
both cues. The increase or deficiency in dietary of VD appears one to be the most critical contributors to in VD status (Clemente-Postigo et al., 2015). The effect on adiposity may be more evident when a higher dose of VD is administered (Mazahery \& von Hurst, 2015) or as in our work a total deficiency orally.

Different genomic and non-genomic mechanisms exerted by VD have been proposed to have a causative role in obesity. It has been established that VD is a modulation hormone with a role in cell proliferation, differentiation and function, may regulate adipose tissue mass, differentiation and metabolism (Kong \& Li; Sun \& Zemel, 2008). The impact of the VDR and its ligand 1,25(OH)2D3 on adipocyte biology is would be regulated by the ligand concentrations 1,25(OH)2D3 (Kong \& Li; Bouillon et al.; Lee et al., 2012). According to Vieth (2009) metabolism in the VD system behaves according to enzyme-kinetic principles. Tissue levels of both 1-hydroxylase and 24-hydroxylase need to be balanced according to the prevailing supply of $25(\mathrm{OH}) \mathrm{D}$ (Vieth et al., 1990; Vieth). When VD supplies are low (intake of diet deficient in VD), the enzymatic capacity of non-renal tissues (adipose tissue) to produce 1,25 $(\mathrm{OH}) 2 \mathrm{D}$ is diminished, stimulating adipogenesis, which is accordingly with our findings.

Mehmood \& Papandreou (2016) indicated low VD status is likely to contribute per se to the development of overweight/obesity. A deficient supply of VD in diet would alter responses of the genes, related to adipocyte differentiation, lipolysis and lipogenesis (Mohamed \& ElAskary, 2017) and therefore could be an underlying cause of obesity exacerbation observed in our research.

Ding et al. (2012) suggests that the vitamin D system is altered in obese subjects and this may have implications for the development of obesity. Morris \& Zemel (2005), suggest a potential role for VD in visceral adiposity. Vimaleswaran et al., indicated increased risk of vitamin D deficiency could contribute to the adverse health effects associated with obesity, powerfully linked with abdominal visceral or subcutaneous adipose tissue (Hannemann et al., 2015). Addition, VD has been associated with regional fat distribution (Caron-Jobin et al., 2011) and with adipocyte size (Caron-Jobin et al.). These mechanisms could explain the results of our study. It may, therefore, be speculated VD deficiency may initiate or exacerbate a process to accumulation of fat tissue. This would suggest that VD deficiency could cause overweight/obesity.

According to Marcotorchino et al. (2014) the weight gain could be explained by a decreased of the ability of vitamin D to limit onset of obesity, via induction of fatty acid oxidation, leading to decreased energy expenditure. Shanmugalingam et al. (2014) suggest an inverse relationship between vitamin $\mathrm{D}$ and obesity.

Concerning our results fat mass in different fat storage sites, effects VD deficiency did not behave similarly among the different fat compartments. This behavior could be for that the depots fat and adipose tissues differ in cellular composition, microvasculature, innervation, metabolic characteristics, extracellular matrix composition, and secretory products (Darimont et al., 2008; Lee et al., 2013). The men accumulate more fat in central area (both VAT and abdominal SAT). In our study the epididymal region was the more influenced by VD deficiency, which relates to the described by Zhang et al. (2015) discovered that visceral fat area was inversely associated with serum $25(\mathrm{OH})$ D3 concentrations, and especially, they have observed that the men had the higher risk for VD insufficiency and deficiency. Additionally, VD deficient may increases the intracellular content of triglycerides with sub-sequent weight gain (Ghavamzadeh et al., 2014) that might explain our results. It is known that tissue adipose, is a metabolically active tissue, have both the nuclear VD receptor (VDR) and the ability to synthesize metabolites VD through the hydroxylase enzymes (1a-hydroxylase) (Li et al., 2008; Ding et al.,) suggesting that adipocytes could be involved in local metabolism and secretion of 1,25-dihydroxy VD3, the bioactive metabolite $(1,25(\mathrm{OH}) 2 \mathrm{D})$ and tissue-specific paracrine effects (Ding et al.). Wamberg et al. (2013) suggested the increased or decreased expression of VDmetabolizing enzymes in adipose tissue as a regulator mechanism of metabolism and both genomic and nongenomic actions of VD. It this could explain the increase of fat mass and body weight in our study. Regardless of genomic or nongenomic action, VD exhibits an important role in modulation of obesity. Evidence shows that VD modulates adipocytes differentiation in several cell models (Dace et al., 1997; Hida et al., 1998).

Zemel \& Sun (2008) suggested a potential role for $\mathrm{VD}$ in regulating energy metabolism and is also contributing to obesity risk (Wong et al., 2009, 2011).

White adipose tissue can be divided into two major stores: subcutaneous and visceral (Wronska \& Kmiec, 2012). The visceral adipose tissue (VAT) dysfunction has been proposed as a major contributor to obesity (Lee et al., 2013). Zhang et al. (2015) confirmed that visceral fat obesity was an important risk factor of VD insufficiency and deficiency among men, and discovered the increase of visceral adiposity was positively associated with VD insufficiency or deficiency. vinh quoc Luong \& Nguyn. suggest a potential role for VD in visceral adiposity, due to its directly regulates adipocyte in 
expression and cortisol production in human adipocytes in vitro (Morris \& Zemel) exerting effect on stimulation of glucocorticoid production. Results of our study revealed that VD deficiency increases the risk of higher visceral fat tissue (epidydimal) in males rat. Which agrees with what has been described in relation to VD deficiency and visceral fat. Zhang et al. (2015) indicated increased visceral fat area was observed to be associated with higher VD deficiency in men, which is confirmed by our results with a significantly increased epididymal fat deposits, which confirms a negative relationship between deficiency VD and overweight/obesity. In comparison of the three major adipose tissue depots of rats, the estimating visceral fat accumulation is important to identify individuals at high risk for VD deficiency.

Another factor that may contribute to the increased adipose mass is the suppression of UCPs (uncoupling proteins) expression in male rats (Wong et al., 2009). Wong et al. (2009), indicated that UCPs are under direct regulation by the VD/VDR signaling, furthermore, showed that VDR overexpression in the adipose tissue led to the suppression of UCP1, UCP2, and UCP3 (Wong et al., 2011). They propose that the trapped VD in adipose tissue were increase the local VD concentration in the fat, and activation or overexpression of the VDR in adipocytes negatively affects energy expenditure, promoting obesity (Wong et al., 2011). Vimaleswaran et al. found evidence for a causal role of deficiency VD in the development of obesity, although a small effect no significant, lower to our results.

This study is the first one to look at the associations between VD deficiency diet intake and risk of overweight and/ or obesity in male rats. In addition, it might be among few studies that assessed overweight/obesity among rat using body weight and fat mass. As overweight/obesity VD deficiency is highly linked to male, the findings have wider implication on designing of prevention strategies for the emerging problem of adult chronic non-communicable diseases and associated morbidity and mortality in deficiency VD diet.

To confirm establishment of VD deficient rat we not measured serum 25-OH VD concentrations at baseline and every week thereafter. Another limitation is the fact that we did not have PTH levels measured and therefore could not test if the observed association between 25(OH)D and body fat might be explained by PTH. However, Park et al. (2015) did not find differences in serum 25-OH VD in obese and lean 22 week old mice (Park et al.). Similarly, Seldeen et al. (2017). There did not find statistically significant difference in serum 25-OH VD between lean and obese mice measured 24 weeks. The consistent inverse relationship between VD and obesity is apparent from observational studies; however, by design, these studies cannot prove causality (Pourshahidi, 2015).

\section{CONCLUSIONS}

In conclusion, results of our study revealed diet intake VD deficiency increases the risk of visceral fat obesity in male's rats and that VD deficiency may be related to variation in regional adiposity. The deficiency VD intake increase adiposity. In addition, the combination of deficiency dietary VD and high fat intake leads to excessive adiposity. In conclusion, our results suggest that deficiency VD intake is associated with body adiposity increase especially abdominal fat and this is impaired VD status associated with obesity could alter metabolic health.

ACKNOWLEDGEMENTS. This work was supported by the FAPERJ/UFRO NºPJ 15-0014, CONICYT-PFCHA / National Doctorate Program /2015-21151103. The authors are grateful to CEMyQ and CEBIOR. University of La Frontera, Temuco. Chile.

MERINO, O.; GREGÓRIO, B.; SAMPAIO, F.; SÁNCHEZ, R. \& RISOPATRÓN, J. Rol de la vitamina D en el desarrollo de la obesidad. Int. J. Morphol., 35(4):1568-1575, 2017.

RESUMEN: Los antecedentes de la literatura sugieren una relación entre la vitamina $\mathrm{D}(\mathrm{VD})$ y el sobrepeso/obesidad, sin embargo, causalidad de la relación no está clara. El presente estudio evaluó el efecto de la ingesta dietética deficiente de VD y alta en grasa sobre el tejido adiposo (TA) y la masa corporal (MC). Los animales se dividieron en cuatro grupos experimentales de acuerdo con el contenido de VD y lípido en la dieta; G1: CVD+ (C: dieta control con VD+; $\mathrm{n}=$ 5), G2: CVD- (dieta control sin VD-; $n=5$ ), G3: HFVD+ (dieta alta en grasa, con VD+; $n=5$ ), G4: HFVD- (dieta HF sin VD-; $n=5$ ). Las dietas se administraron durante tres meses y MC se controló semanalmente. Al final de este período, los animales fueron sacrificados. La masa grasa epididimaria (MGE), subcutánea abdominal (MGS) y retroperitoneal (MGR) fueron diseccionadas y pesadas individualmente. A las 12 semanas, la $\mathrm{MC}$ de los animales alimentados con dietas sin VD-; G2: 507,60 $\pm 17,31 \mathrm{~g}, \mathrm{y}$ G4: $528,50 \pm 13,50 \mathrm{~g}$ fue significativamente mayor ( $\mathrm{p}<0,05$ ), que sus homólogos G1: 485,0 \pm $11,29 \mathrm{~g}$ y G3: $521,20 \pm 26,20 \mathrm{~g}$ respectivamente. De forma similar, los G2 y G4 tuvieron una mayor MGE y MGS ( $<<0,05)$ en comparación con los controles respectivos (VD+). Sin embargo, los animales alimentados con dieta alta en grasas tuvieron igual MGR (G3: 12,2 \pm 4,10 g; G4: 12,88 $\pm 2,3 \mathrm{~g}, \mathrm{p}>0,05$ ). Los resultados demuestran que la nutrición de ratas con dieta deficiente en VD y alta en grasa, promueve el sobrepeso/obesidad al exacerbar la ganancia de masa grasa en los diferentes depósitos de grasa, sugiriendo una relación causa-efecto entre la deficiencia de VD y el sobrepeso/obesidad. Estos resultados sugieren que la deficiencia de VD aumenta el riesgo de obesidad de grasa visceral en machos.

PALABRAS CLAVE: Deficiencia de VD; Ganancia de masa corporal; Ganancia de masa grasa; Deposito de grasa; Obesidad grasa visceral. 


\section{REFERENCES}

Borges, C. C.; Salles, A. F.; Bringhenti, I.; Souza-Mello, V.; Mandarim-deLacerda, C. A. \& Aguila, M. B. Adverse effects of vitamin D deficiency on the Pi3k/Akt pathway and pancreatic islet morphology in dietinduced obese mice. Mol. Nutr. Food Res., 60(2):346-57, 2016.

Bouillon, R.; Carmeliet, G.; Verlinden, L.; van Etten, E.; Verstuyf, A.; Luderer, H. F.; Mathieu, C. \& Demay, M. Vitamin D and human health: lessons from vitamin D receptor null mice. Endocr. Rev., 29(6):72676, 2008.

Caron-Jobin, M.; Morisset, A. S.; Tremblay, A.; Huot, C.; Légaré, D. \& Tchernof, A. Elevated serum 25(OH)D concentrations, vitamin D, and calcium intakes are associated with reduced adipocyte size in women. Obesity (Silver Spring), 19(7):1335-41, 2011.

Chang, E. \& Kim, Y. Vitamin D insufficiency exacerbates adipose tissue macrophage infiltration and decreases AMPK/SIRT1 activity in obese rats. Nutrients, 9(4):E338, 2017.

Clemente-Postigo, M.; Muñoz-Garach, A.; Serrano, M.; Garrido-Sánchez, L.; Bernal-López, M. R.; Fernández-García, D.; Moreno-Santos, I.; Garriga, N.; Castellano-Castillo, D.; Camargo, A.; Fernández-Real, J. M.; Cardona, F.; Tinahones, F. J. \& Macías-González, M. Serum 25hydroxyvitamin $\mathrm{D}$ and adipose tissue vitamin $\mathrm{D}$ receptor gene expression: relationship with obesity and type 2 diabetes. J. Clin. Endocrinol. Metab., 100(4):E591-5, 2015.

Dace, A.; Martin-el Yazidi, C.; Bonne, J.; Planells, R. \& Torresani, J. Calcitriol is a positive effector of adipose differentiation in the $\mathrm{OB} 17$ cell line: relationship with the adipogenic action of triiodothyronine. Biochem. Biophys. Res. Commun., 232(3):771-6, 1997.

Darimont, C.; Avanti, O.; Blancher, F.; Wagniere, S.; Mansourian, R.; Zbinden, I.; Leone-Vautravers, P.; Fuerholz, A.; Giusti, V. \& Macé, K. Contribution of mesothelial cells in the expression of inflammatoryrelated factors in omental adipose tissue of obese subjects. Int. J. Obes. (Lond.), 32(1):112-20, 2008.

Demay, M. B. Mechanism of vitamin D receptor action. Ann. N. Y. Acad. Sci., 1068:204-13, 2006.

Ding, C.; Gao, D.; Wilding, J.; Trayhurn, P. \& Bing, C. Vitamin D signalling in adipose tissue. Br. J. Nutr., 108(11):1915-23, 2012.

Fox, C. S.; Massaro, J. M.; Hoffmann, U.; Pou, K. M.; Maurovich-Horvat, P.; Liu, C. Y.; Vasan, R. S.; Murabito, J. M.; Meigs, J. B.; Cupples, L. A.; D'Agostino, R. B. Sr. \& O'Donnell, C. J. Abdominal visceral and subcutaneous adipose tissue compartments: association with metabolic risk factors in the Framingham Heart Study. Circulation, 116(1):3948, 2007.

Ghavamzadeh, S.; Mobasseri, M. \& Mahdavi, R. The effect of vitamin D supplementation on adiposity, blood glycated hemoglobin, serum leptin and Tumor Necrosis Factor-a in type 2 diabetic patients. Int. J. Prev. Med., 5(9):1091-8, 2014.

Hannemann, A.; Thuesen, B. H.; Friedrich, N.; Völzke, H.; Steveling, A.; Ittermann, T.; Hegenscheid, K.; Nauck, M.; Linneberg, A. \& Wallaschofski, H. Adiposity measures and vitamin D concentrations in Northeast Germany and Denmark. Nutr. Metab. (Lond.), 12:24, 2015.

Hida, Y.; Kawada, T.; Kayahashi, S.; Ishihara, T. \& Fushiki, T. Counteraction of retinoic acid and 1,25-dihydroxy vitamin D3 on up-regulation of adipocyte differentiation with PPAR g ligand, an antidiabetic thiazolidinedione, in 3T3-L1 cells. Life Sci., 62(14):PL205-11, 1998.

Holick, M. F. \& Chen, T. C. Vitamin D deficiency: a worldwide problem with health consequences. Am. J. Clin. Nutr., 87(4):1080S-6S, 2008.

Hossein-nezhad, A. \& Holick, M. F. Optimize dietary intake of vitamin D: an epigenetic perspective. Curr. Opin. Clin. Nutr. Metab. Care, 15(6):567-79, 2012.

James, P. T.; Leach, R.; Kalamara, E. \& Shayeghi, M. The worldwide obesity epidemic. Obes. Res., 9 Suppl. 4:228S-33S, 2001.

Kayaniyil, S.; Vieth, R.; Harris, S. B.; Retnakaran, R.; Knight, J. A.; Gerstein, H. C.; Perkins, B. A.; Zinman, B. \& Hanley, A. J. Association of
25(OH)D and PTH with metabolic syndrome and its traditional and nontraditional components. J. Clin. Endocrinol. Metab., 96(1):168-75, 2011.

Kong, J. \& Li, Y. C. Molecular mechanism of 1,25-dihydroxyvitamin D3 inhibition of adipogenesis in 3T3-L1 cells. Am. J. Physiol. Endocrinol. Metab., 290(5):E916-24, 2006.

Koszowska, A. U.; Nowak, J.; Dittfeld, A.; Bronczyk-Puzon, A.; Kulpok, A. \& Zubelewicz-Szkodzin'ska, B. Obesity, adipose tissue function and the role of vitamin D. Cent. Eur. J. Immunol., 39(2):260-4, 2014.

Lee, J. J.; Drakaki, A.; Iliopoulos, D. \& Struhl, K. MiR-27b targets PPARg to inhibit growth, tumor progression and the inflammatory response in neuroblastoma cells. Oncogene, 31(33):3818-25, 2012.

Lee, S. H.; Kim, S. M.; Park, H. S.; Choi, K. M.; Cho, G. J.; Ko, B. J. \& Kim, J. H. Serum 25-hydroxyvitamin D levels, obesity and the metabolic syndrome among Korean children. Nutr. Metab. Cardiovasc. Dis., 23(8):785-91, 2013.

Lehr, S.; Hartwig, S.; Lamers, D.; Famulla, S.; Müller, S.; Hanisch, F. G.; Cuvelier, C.; Ruige, J.; Eckardt, K.; Ouwens, D. M.; Sell, H. \& Eckel, J. Identification and validation of novel adipokines released from primary human adipocytes. Mol. Cell. Proteomics, 11:M111.010504, 2012.

Li, J.; Byrne, M. E.; Chang, E.; Jiang, Y.; Donkin, S. S.; Buhman, K. K.; Burgess, J. R. \& Teegarden, D. 1alpha,25-Dihydroxyvitamin D hydroxylase in adipocytes. J. Steroid. Biochem. Mol. Biol., 112(13):122-6, 2008.

Malmberg, P.; Karlsson, T.; Svensson, H.; Lönn, M.; Carlsson, N. G.; Sandberg, A. S.; Jennische, E.; Osmancevic, A. \& Holmäng, A. A new approach to measuring vitamin $\mathrm{D}$ in human adipose tissue using timeof-flight secondary ion mass spectrometry: a pilot study. J. Photochem. Photobiol. B, 138:295-301, 2014.

Marcotorchino, J.; Tourniaire, F.; Astier, J.; Karkeni, E.; Canault, M.; Amiot, M. J.; Bendahan, D.; Bernard, M.; Martin, J. C.; Giannesini, B. \& Landrier, J. F. Vitamin D protects against diet-induced obesity by enhancing fatty acid oxidation. J. Nutr. Biochem., 25(10):1077-83, 2014.

Mazahery, H. \& von Hurst, P. R. Factors Affecting 25-hydroxyvitamin D concentration in response to vitamin D supplementation. Nutrients, 7(7):5111-42, 2015

Mehmood, Z. H. \& Papandreou, D. An Updated mini review of vitamin D and obesity: Adipogenesis and inflammation state. Open Access Maced. J. Med. Sci., 4(3):526-32, 2016.

Mohamed, S. \& El-Askary, A. Vitamin D receptor gene polymorphism among Egyptian obese children. Asian J. Clin. Nutr., 9(1):24-9, 2017.

Morris, K. L. \& Zemel, M. B. 1,25-dihydroxyvitamin D3 modulation of adipocyte glucocorticoid function. Obes. Res., 13(4):670-7, 2005.

Narvaez, C. J.; Matthews, D.; Broun, E.; Chan, M. \& Welsh, J. Lean phenotype and resistance to diet-induced obesity in vitamin D receptor knockout mice correlates with induction of uncoupling protein-1 in white adipose tissue. Endocrinology, 150(2):651-61, 2009.

Nishimura, S.; Manabe, I.; Nagasaki, M.; Hosoya, Y.; Yamashita, H.; Fujita, H.; Ohsugi, M.; Tobe, K.; Kadowaki, T.; Nagai, R. \& Sugiura, S. Adipogenesis in obesity requires close interplay between differentiating adipocytes, stromal cells, and blood vessels. Diabetes, 56(6):1517-26, 2007.

Park, J. M.; Park, C. Y. \& Han, S. N. High fat diet-Induced obesity alters vitamin D metabolizing enzyme expression in mice. Biofactors, 41(3):175-82, 2015

Popkin, B. M. Recent dynamics suggest selected countries catching up to US obesity. Am. J. Clin. Nutr., 91(1):284S-288S, 2010.

Pourshahidi, L. K. Vitamin D and obesity: current perspectives and future directions. Proc. Nutr. Soc., 74(2):115-24, 2015.

Reeves, P. G.; Nielsen, F. H. \& Fahey, G. C. Jr. AIN-93 purified diets for laboratory rodents: final report of the American Institute of Nutrition ad hoc writing committee on the reformulation of the AIN-76A rodent diet. J. Nutr., 123(11):1939-51, 1993.

Seldeen, K. L.; Pang, M.; Rodríguez-Gonzalez, M.; Hernandez, M.; Sheridan, Z.; Yu, P. \& Troen, B. R. A mouse model of vitamin D 
insufficiency: is there a relationship between $25(\mathrm{OH})$ vitamin D levels and obesity? Nutr. Metab. (Lond.), 14(1):26, 2017.

Shanmugalingam, T.; Crawley, D.; Bosco, C.; Melvin, J.; Rohrmann, S.; Chowdhury, S.; Holmberg, L. \& Van Hemelrijck, M. Obesity and cancer: the role of vitamin D. B. M. C. Cancer, 14:712, 2014.

Sun, X. \& Zemel, M. B. Calcitriol and calcium regulate cytokine production and adipocyte-macrophage cross-talk. J. Nutr. Biochem., 19(6):392-9, 2008.

Taylor, B. A. \& Phillips, S. J. Detection of obesity QTLs on mouse chromosomes 1 and 7 by selective DNA pooling. Genomics, 34(3):38998, 1996.

Vieth, R. Vitamin D and cancer mini-symposium: the risk of additional vitamin D. Ann. Epidemiol., 19(7):441-5, 2009.

Vieth, R.; McCarten, K. \& Norwich, K. H. Role of 25-hydroxyVD3 dose in determining rat 1,25 -dihydroxyvitamin $\mathrm{D} 3$ production. Am. $J$. Physiol. Endocrinol. Metab., 258(5):E780-9, 1990.

Vimaleswaran, K. S.; Berry, D. J.; Lu, C.; Tikkanen, E.; Pilz, S.; Hiraki, L. T.; Cooper, J. D.; Dastani, Z.; Li, R.; Houston, D. K.; Wood, A. R.; Michaëlsson, K.; Vandenput, L.; Zgaga, L.; Yerges-Armstrong, L. M.; McCarthy, M. I.; Dupuis, J.; Kaakinen, M.; Kleber, M. E.; Jameson, K.; Arden, N.; Raitakari, O.; Viikari, J.; Lohman, K. K.; Ferrucci, L.; Melhus, H.; Ingelsson, E.; Byberg, L.; Lind, L.; Lorentzon, M.; Salomaa, V.; Campbell, H.; Dunlop, M.; Mitchell, B. D.; Herzig, K. H.; Pouta, A.; Hartikainen, A. L.; Genetic Investigation of Anthropometric TraitsGIANT Consortium; Streeten, E. A.; Theodoratou, E.; Jula, A.; Wareham, N. J.; Ohlsson, C.; Frayling, T. M.; Kritchevsky, S. B.; Spector, T. D.; Richards, J. B.; Lehtimäki, T.; Ouwehand, W. H.; Kraft, P.; Cooper, C.; März, W.; Power, C.; Loos, R. J.; Wang, T. J.; Järvelin, M. R.; Whittaker, J. C.; Hingorani, A. D. \& Hyppönen, E. Causal relationship between obesity and vitamin D status: bi-directional Mendelian randomization analysis of multiple cohorts. PLoS Med., 10(2):e1001383, 2013.

vinh quoc Luong, K. \& Nguyn, L. T. The beneficial role of vitamin D in obesity: possible genetic and cell signaling mechanisms. Nutr. J., 12:89, 2013

Wamberg, L.; Christiansen, T.; Paulsen, S. K.; Fisker, S.; Rask, P.; Rejnmark, L.; Richelsen, B. \& Pedersen, S. B. Expression of vitamin Dmetabolizing enzymes in human adipose tissue -- the effect of obesity and diet-induced weight loss. Int. J. Obes. (Lond.), 37(5):651-7, 2013.

Wong, K. E.; Kong, J.; Zhang, W.; Szeto, F. L.; Ye, H.; Deb, D. K.; Brady, M. J. \& Li, Y. C. Targeted expression of human vitamin D receptor in adipocytes decreases energy expenditure and induces obesity in mice. J. Biol. Chem., 286(39):33804-10, 2011.

Wong, K. E.; Szeto, F. L.; Zhang, W.; Ye, H.; Kong, J.; Zhang, Z.; Sun, X. J. \& Li, Y. C. Involvement of the vitamin D receptor in energy metabolism: regulation of uncoupling proteins. Am. J. Physiol. Endocrinol. Metab., 296(4):E820-8, 2009.

World Health Organization. Obesity: Preventing and Managing the Global Epidemic. ( $\left.N^{\circ} 894\right)$. Geneve, World Health Organization, 2000.

Wronska, A. \& Kmiec, Z. Structural and biochemical characteristics of various white adipose tissue depots. Acta Physiol. (Oxf.), 205(2):194208, 2012.

Zemel, M. B. \& Sun, X. Calcitriol and energy metabolism. Nutr. Rev., 66(10 Suppl. 2):S139-46, 2008.

Zhang, M.; Li, P.; Zhu, Y.; Chang, H.; Wang, X.; Liu, W. \& Huang, G. Higher visceral fat area increases the risk of vitamin D insufficiency and deficiency in Chinese adults. Nutrition \& metabolism, 12:50, 2015.
Corresponding author:

Prof. M.Sc. Jennie Risopatrón

Center of Biotechnology on Reproduction

(BIOREN- CEBIOR)

Faculty of Medicine

Universidad de La Frontera

Montevideo 0870

Temuco

CHILE

E-mail: jennie.risopatron@ufrontera.cl

Received : 16-07-2017

Accepted : 19-09-2017 